\title{
GREENING THE SUPPLY CHAIN IN CORPORATE RESPONSIBILITY
}

\author{
Iryna Kalenyuk ${ }^{1}$, Liudmyla Tsymbal ${ }^{2}$, Rustam Aslanzade ${ }^{3}$ \\ ${ }^{1}$ Prof. Dr. Kyiv National Economy University Named After Vadym Hetman. Address: 54/1 Prospect \\ Peremogy03057 Kyiv, Ukraine. Tel.+38096 7505810.E-mail kalenuk@ukr.net \\ ${ }^{2}$ Assoc. Prof. Dr. Kyiv National Economy University Named After Vadym Hetman. Address: 54/1 \\ Prospect Peremogy 03057 Kyiv, Ukraine.Tel. +380 93 2395608. E-mail l.tsimbal@ukr.net \\ ${ }^{3}$ Student PhD ISMA University. Address: 1 Lomonosova Str., build. 6. Riga, Latvia, LV-1019. \\ Tel.+994 5021562 15. E-mail: rustam.aslan@gmail.com
}

Received 0311 2019; accepted 20122019

\begin{abstract}
A feature of the development of the modern global economy is the strengthening of social responsibility of business. All entrepreneurial activity is carried out taking into account the interests of society, the team, nature. The article analyzes the current trends in greening the business, including the supply chains of leading companies in the world. The main indicators of environmental sustainability of supply chains are highlighted. The growing importance of social responsibility in the activities of companies, its implementation along the whole chain is proved. An analysis of the most common sustainability ratings of global companies confirmed that social responsibility has an increasing trend, becoming an important characteristic of modern business and a powerful competitive advantage.
\end{abstract}

Keywords: corporate responsibility, supply chain management, corporate sustainability, efficient supply chain, environment sustainability.

JEL codes: Q12; Q18.

\section{Introduction}

The enterprises require to constantly develop existing technologies and management practices in the view of rapid changes in the modern business environment. Moreover, such development necessarily includes an increased focus on social problems, which is manifested in the spread of the concept of corporate social responsibility or social responsibility of business (hereinafter referred as CSR). For both society and business, an increased focus on social problems is one of the most important contemporary trends. The concept of corporate social responsibility is based on the principles of focusing on the social problems of consumers, company personnel, and other stakeholders.

In modern business practice, adherence to the principles of corporate social responsibility is becoming an integral feature of the business management system. The environmental focus is a component of corporate social responsibility for business.

Copyright (C) 2019 The Authors. Published by Vytautas Magnus University. This is an open-access article distributed under the terms of the Creative Commons Attribution-NonCommercial 4.0 (CC BY-NC 4.0) license, which permits unrestricted use, distribution, and reproduction in any medium, provided the original author and source are credited. The material cannot be used for commercial purposes. 
The business main objectives, such as increasing added value and making profit, are to be achieved due to the consistent implementation of environmental values in all areas of commercial activity without doing any harm to people, nature, and society. As for any modern and civilized business, which is focused on sustainable development, this should become a normal and ordinary practice in the contemporary context.

Thus, the social responsibility is not just a modality, but it is a clear emphasis on the company's activities permeating all areas and directions. Such a sphere as supply chain management is an important direction in the implementation of the CSR concept in modern business. Building an end-to-end supply chain on the principles of sustainable development is an urgent problem of modern business theory and practice.

The study of the problems of managing the entire supply chain (from the idea up to supply to the final consumer), the consistent implementation of the principles of "sustainability", and "greening" in the supply chain functioning, assessing the degree of social responsibility of in this company's supply chain, etc is promising many opportunities. Ceased to be linear, the general chain and forms a feedback, which transforms it into a closed-loop chain. Construction of an integrated chain involves strengthening coordination between all of its elements; thus, the ultimate goal is to improve a customer's satisfaction (Prashant K. \& Subhash W., 2014).

Scientific literature review and modelling methods suggested quantitative empirical study to be performed in finding actual evidence for solutions of defined scientific problem. Descriptive statistical analysis and visualization methods were applied to organize the research results.

The article's purpose is to study the processes of spreading of the CSR (Corporate Social Responsibility) concept in the supply chain management.

\section{Results and discussion}

At the present stage of the global market's development, greening and socialization of the supply chains is a prerequisite for ensuring a company's competitiveness. The company also forms its advantages at each stage (see Fig.1), as its socially active position not only forms a positive vision of the business, but also brings certain economic benefits, forming a supply chain from making the concept up to processing of the finished product after use.

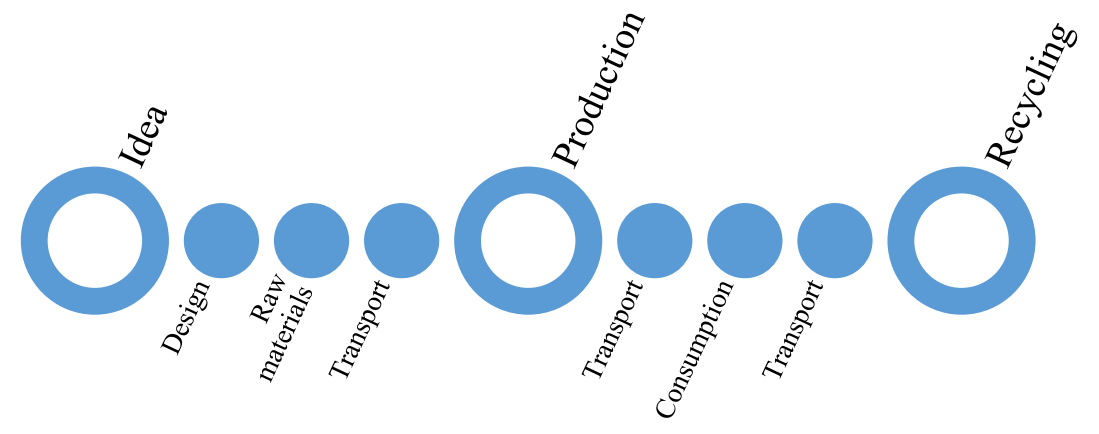

Fig. 1. Building supply chain based on principles of social responsibility 
Applying the social responsibility principle in the supply chain reveals due to arrangement of a format that is environmentally positive or focused on human at all supply stages, and due to adherence to these principles at all stages of the product's life cycle, and even after the product consumption. Such concepts as "sustainability" and "greening" are revealed by two key points: on the one hand, applying these concepts we minimize the use of raw materials, energy, water, thus we make less garbage and wastes; on the other hand, we maximize the positive effects of production, thus we get better environmental standards, we get more environmental benefits and profit, and we improve human capital management and enrichment.

More than $90 \%$ of the company executives have publicly declared the goals and policies aimed at corporate sustainability, and $74 \%$ of the companies associate the company's development success with the declaration of corporate social and environmental responsibility. Even though more than $70 \%$ of the resources are located outside the production facilities, only $20 \%$ of the company's focus on creating the entire network with a high CSR level (Cecere L.). In assessing corporate responsibility, the ultimate part consists of the environmental responsibility, the company's internal relations, and environmental impacts (see Table 1).

Table 1. The best companies' performance evaluation according to the corporate social responsibility parameters of (100 best ..., 2019)

\begin{tabular}{|l|c|c|}
\hline \multicolumn{1}{|c|}{ Indicator group } & Weight $(\%$ of total) & The number of factors in the group \\
\hline Climate change & 18,0 & 27 \\
\hline Employee Relations & 20,5 & 24 \\
\hline Environment & 18,0 & 28 \\
\hline Finance & 4,5 & 8 \\
\hline Control & 7,5 & 10 \\
\hline $\begin{array}{l}\text { Management: ISS-ESG: } \\
\text { Corporate Ranking }\end{array}$ & 8,0 & 2 \\
\hline Human rights & 11,0 & 17 \\
\hline Stakeholders and Society & 12,5 & 18 \\
\hline Total & 100 & 134 \\
\hline
\end{tabular}

The largest number of factors that are included in the evaluation of the company's social responsibility correlates with the indicators of environmental impact and relations with the employees, which indicates on an attempt to maximize the companies' involvement in preserving environmental factors in all forms of appearance. At the beginning of the 21 st century of the annual rating " 100 best corporate citizens", a specific attention was focused on assessment of the corporate social responsibility of business. According to the data for 2018, the best companies in the world with the highest rates of corporate social responsibility are located in the USA (see Table 2). 
Table 2. TOP-20 companies with the highest rates of social responsibility, 2018 (100 best ..., 2019)

\begin{tabular}{|c|c|c|c|c|c|c|c|c|c|c|c|}
\hline 䒕 & 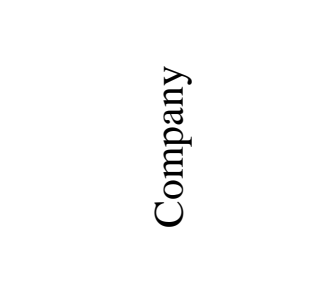 & $\begin{array}{l}\overline{8} \\
\text { ह } \\
\text { त }\end{array}$ & 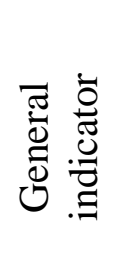 & 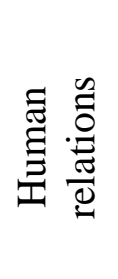 & 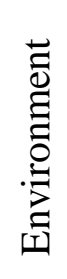 & 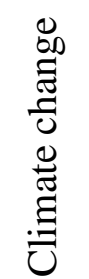 & 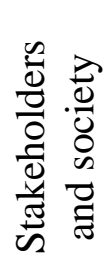 & 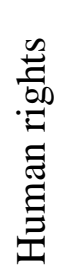 & 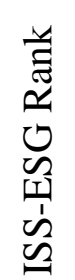 & 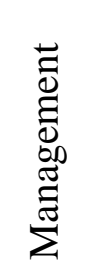 & 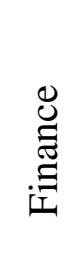 \\
\hline 1. & $\begin{array}{l}\text { OWENS } \\
\text { CORNING }\end{array}$ & $\mathrm{OC}$ & 84,97 & 42 & 47 & 31 & 6 & 1 & 1 & 346 & 116 \\
\hline 2. & INTEL CORP. & INTC & 83,32 & 4 & 5 & 13 & 7 & 65 & 2 & 704 & 8 \\
\hline 3. & $\begin{array}{l}\text { GENERAL } \\
\text { MILLS, INC. }\end{array}$ & GIS & 82,72 & 30 & 84 & 9 & 9 & 13 & 95 & 466 & 65 \\
\hline 4. & $\begin{array}{l}\text { CAMPBELL } \\
\text { SOUP CO. }\end{array}$ & $\mathrm{CPB}$ & 80,84 & 143 & 36 & 101 & 11 & 12 & 96 & 34 & 110 \\
\hline 5. & HP, INC. & HPQ & 80,69 & 41 & 71 & 1 & 41 & 76 & 97 & 35 & 140 \\
\hline 6. & $\begin{array}{l}\text { MICROSOFT } \\
\text { CORP. }\end{array}$ & MSFT & 80,09 & 114 & 65 & 162 & 3 & 10 & 98 & 99 & 19 \\
\hline 7. & $\begin{array}{l}\text { NIELSEN } \\
\text { HOLDINGS PLC }\end{array}$ & NLSN & 79,91 & 29 & 30 & 308 & 15 & 4 & 3 & 36 & 795 \\
\hline 8. & ECOLAB, INC. & ECL & 79,81 & 18 & 24 & 153 & 58 & 9 & 57 & 347 & 658 \\
\hline 9. & GAP, INC. & GPS & 78,01 & 16 & 49 & 140 & 80 & 11 & 151 & 194 & 762 \\
\hline 10. & $\begin{array}{l}\text { CISCO } \\
\text { SYSTEMS, INC. }\end{array}$ & CSCO & 77,22 & 100 & 50 & 32 & 49 & 41 & 41 & 348 & 372 \\
\hline
\end{tabular}

In modern business environment, an effective supply chain engineering is a competitive advantage; therefore, the companies hold regular assessment of their efficiency and effectiveness. Gartner, Inc. Global Ranking (Supply Chain TOP-25) defines the leaders by supply chain efficiency. In 2019, two new entrants were included in the ranking (one from the retail sector, and one from the chemical industry); ColgatePalmolive is the global leader, followed by Inditex, Nestlé, PepsiCo, and Cisco (Table $3)$.

Table 3. TOP 10 companies in the world with the most efficient supply chains, 2019 (Gartner, 2019)

\begin{tabular}{|c|l|c|c|c|c|c|c|c|}
\hline Rank & Company & $\begin{array}{c}\text { Opinion } \\
(162 \text { voters } \\
(25 \%)\end{array}$ & $\begin{array}{c}\text { Opinion } \\
\text { Gartner (38 } \\
\text { voters) } \\
(25 \%)\end{array}$ & $\begin{array}{c}\text { Three-year } \\
\text { weighted } \\
\text { ROA } \\
(20 \%)\end{array}$ & $\begin{array}{c}\text { Inventory } \\
\text { turnover } \\
(10 \%)\end{array}$ & $\begin{array}{c}\text { Three-year } \\
\text { weighted } \\
\text { revenue } \\
\text { growth } \\
(10 \%)\end{array}$ & $\begin{array}{c}\text { CSR } \\
\text { component } \\
\text { rating } \\
(10 \%)\end{array}$ & $\begin{array}{c}\text { Composite } \\
\text { score }\end{array}$ \\
\hline 1. & $\begin{array}{l}\text { Colgate- } \\
\text { Palmolive }\end{array}$ & 961 & 347 & $19,9 \%$ & 5,0 & $-0,2 \%$ & 10,00 & 4,88 \\
\hline 2. & Inditex & 1,091 & 341 & $16,2 \%$ & 3,8 & $6,5 \%$ & 10,00 & 4,80 \\
\hline 3. & Nestlé & 1,262 & 374 & $6,9 \%$ & 4,8 & $1,2 \%$ & 10,00 & 4,27 \\
\hline 4. & PepsiCo & 997 & 368 & $11,7 \%$ & 9,0 & $1,2 \%$ & 8,00 & 4,22 \\
\hline 5. & $\begin{array}{l}\text { Cisco } \\
\text { Systems }\end{array}$ & 699 & 518 & $4,0 \%$ & 10,2 & $0,7 \%$ & 10,00 & 4,13 \\
\hline
\end{tabular}




\begin{tabular}{|c|l|c|c|c|c|c|c|c|}
\hline 6. & Intel & 576 & 454 & $12,4 \%$ & 3,7 & $9,6 \%$ & 6,00 & 4,12 \\
\hline 7. & HP Inc. & 293 & 353 & $11,7 \%$ & 8,2 & $7,3 \%$ & 10,00 & 3,81 \\
\hline 8. & $\begin{array}{l}\text { Johnson } \\
\text { \& } \\
\text { Johnson }\end{array}$ & 737 & 348 & $7,6 \%$ & 3,1 & $5,8 \%$ & 10,00 & 3,80 \\
\hline 9. & Starbucks & 900 & 167 & $19,3 \%$ & 12,7 & $9,0 \%$ & 4,00 & 3,74 \\
\hline 10. & Nike & 1,194 & 186 & $13,3 \%$ & 3,9 & $6,0 \%$ & 4,00 & 3,73 \\
\hline
\end{tabular}

The report emphasizes that automation and digitalization are important components of leadership if assessed by the criteria for the effective supply chains engineering (Gartner, 2019). The best practice of solving new problems arising in such supply chains are taken into account (such as involving local specialists for advanced training, minimizing plastic wastes, minimizing water pollution, forming an ecosystem, communication with external partners, etc.).

It is among the companies that are global leaders we can find the best practice for implementing corporate responsibility. At Northrop Grumman company has indicated on such basic indicators of corporate social responsibility in their reports: the representation of women and men of different races in the company management (such as presence of women at the level of vice-president and above has increased from $16 \%$ to 33\%; and People of Color representation at the level of vice president and above has increased from $11 \%$ to $18 \%$ ); the employee training (at least $50 \%$ of employees are trained); involving small businesses in supply chains (more than $23 \%$ of suppliers and $37 \%$ of subcontractors are involved); environmental responsibility (reducing of greenhouse gas emissions by $33 \%$, sustainable water consumption, and solid waste processing); occupational training and student support (\$20 million for training programs).

In addition, the company sets the standard for behaviour for all suppliers, employees, and subcontractors at all levels. Northrop Grumman develops and maintains a diverse supply chain that provides optimal value for the enterprise and customers. The Northrop Grumman Global Supplier Diversity Program Office (GSDP) is the gateway to small and low-income business owners, as well as the partners at colleges and universities.

During 2018 fiscal year, the company subcontracted $37 \%$ of domestic procurement costs ( $\$ 3.1$ billion) with small business suppliers, since the United States government has established the statutory minimum participation rates for small businesses in supply chains, while Northrop Grumman has reached and exceeded the target indexes established by the law in the US at the rate of 23\% (Figure 1). 


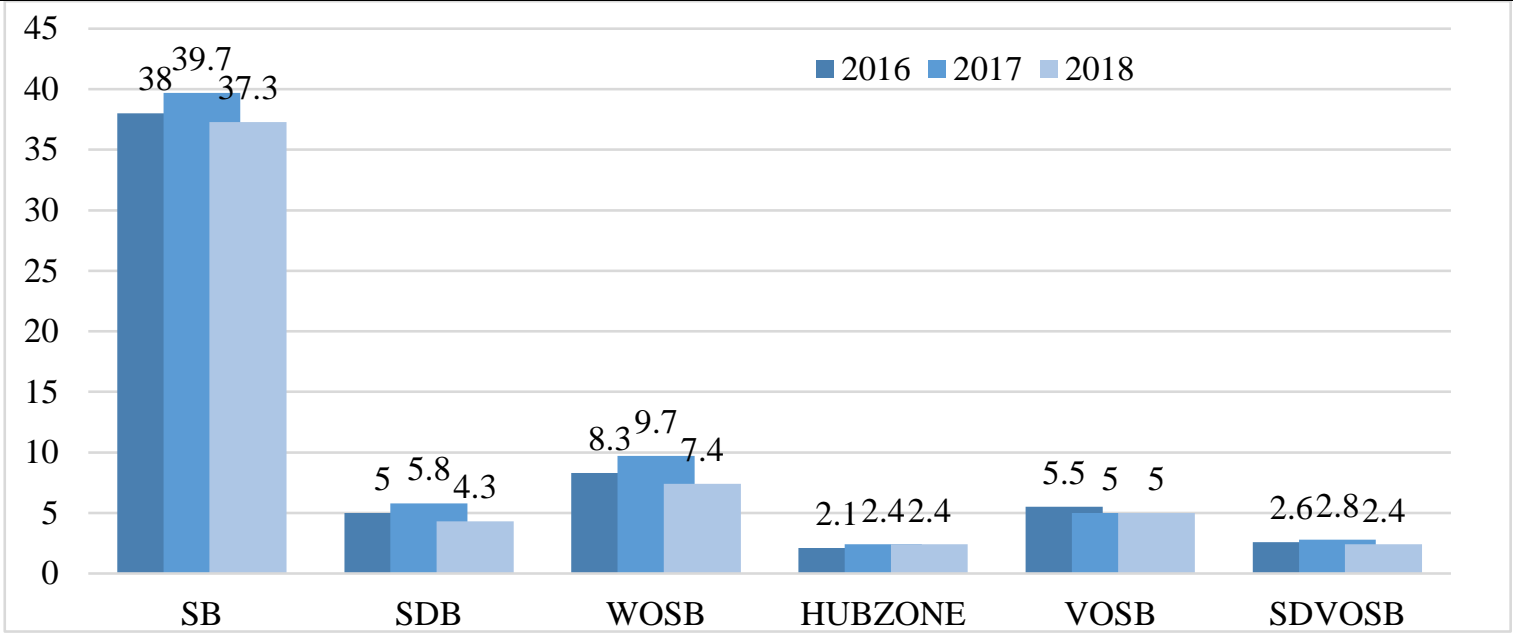

Fig. 1. The company's various suppliers' ratio in \%, as of 2018 (Corporate responsibility, 2018)

SB is a small business;

SDB is a small dysfunctional business (SDB) (it is a small business that at least 51 percent belongs to one or more individuals who are in a disadvantaged social and economic situation).

WOSB is a small business owned by women.

HUDZONE is a historically underutilized business area.

VOSB is a small business founded by the Armed Forces veterans.

SDVOSB that is Service-Disabled Veteran-Owned Small Business, a small business founded by veterans with disabilities.

The control upon supply chains focuses on avoiding reducing the product's quality at all stages of its production, counterfeit parts and adhering cybersecurity rules, protecting intellectual property, for which a special program has been developed in order to train how to define authenticity of the materials for the entire supply chain, improving product quality, engineering, etc. Thus, only those suppliers who have been trained or tested to prevent counterfeit products' production or getting into the supply chain are allowed (Corporate responsibility, 2018).

A similar strategy is supported by a huge number of companies in the world, including: Target (the company joined the Nest Standards Platform to develop 130 compliance standards for human rights, child protection, health and safety throughout the supply chain, RBA and LaborLink initiatives) (Future ..., 2018); VINCI (SCSS, Constructionline, the local small business' share in the supply chain in 2017 grew from 73 to $78 \%$ (in total, the company has 4,792 suppliers, $85 \%$ of which are certified at the security schemes, and $70 \%$ of them are registered in Constructiononline, SCRIA (Sustainbility ..., 2018); iPortal Construction Line ( Supply chain, 2018); ACS Group Directory, in which supplier and contractor management is an important aspect, because the work they do has a direct impact on the quality of the project's final result implemented by the company (Suppliers and ..., 2018). The Company has developed certain criteria for non-financial performance evaluation of its suppliers (see Table 4). 
Table 4. The extent of adoption of non-financial criteria when approving the suppliers for ACS Group Directory (\%) (Suppliers and ..., 2018)

\begin{tabular}{|l|c|c|}
\hline \multicolumn{1}{|c|}{ Criterions } & 2017 & 2018 \\
\hline Compliance with the ACS Group Code of Conduct & $97,0 \%$ & $96,9 \%$ \\
\hline $\begin{array}{l}\text { Compliance and compliance with international human rights } \\
\text { standards and labor market rules }\end{array}$ & $90,3 \%$ & $92,7 \%$ \\
\hline Certification according to quality standards (ISO9001) & $98,2 \%$ & $99,5 \%$ \\
\hline Environmental certification (ISO14001, EMAS or equivalent) & $98,3 \%$ & $99,5 \%$ \\
\hline $\begin{array}{l}\text { Analysis of labor standards and practices of suppliers or } \\
\text { subcontractors }\end{array}$ & $96,2 \%$ & 98,45 \\
\hline
\end{tabular}

Similarly, given the importance of supply chain analysis for risk management, the ACS Group of companies have begun to identify the key suppliers among their direct suppliers. ACS Group has evaluated 2307 suppliers, which are considered the best in the terms of sustainability in 2018. Having analysed the experience of most companies with developed supply chains, it is necessary to note that the responsible supply chain engineering is implemented in several key aspects (see Table 5).

Table 5. The aspects of forging relationships with some stakeholders (Management..., 2018)

\begin{tabular}{|l|l|l|}
\hline Stakeholders & \multicolumn{1}{|c|}{ Relevant areas for stakeholders } & \multicolumn{1}{|c|}{ Relationship mechanisms and bodies } \\
\hline Workers & $\begin{array}{l}\text { - people } \\
\text { - healthy and safe management } \\
\text { - transparency, ethics and honesty } \\
\text { - feedback to society }\end{array}$ & $\begin{array}{l}\text { - personnel departments of companies } \\
\text { - efficiency mark } \\
\text { - ethics channel } \\
\text { - prevention committee }\end{array}$ \\
\hline $\begin{array}{l}\text { Suppliers and } \\
\text { subcontractors }\end{array}$ & $\begin{array}{l}\text { - contracting with the ACS group } \\
\text { - payment option } \\
\text { - health and safety management } \\
\text { - transparency, ethics and honesty }\end{array}$ & $\begin{array}{l}\text { - vendorement approval and management process } \\
\text { - ethical rules }\end{array}$ \\
\hline $\begin{array}{l}\text { Industry } \\
\text { Associations }\end{array}$ & $\begin{array}{l}\text { all aspects mentioned above } \\
\text { garticipation in associations, working } \\
\text { groups and discussion forums }\end{array}$ \\
\hline
\end{tabular}

Overall, large companies adhere to the social responsibility principles and form their development strategies based on these principles. For the most part, they require providing supply chain engineering from the companies that adhere to similar values or impose their values on them by signing an Agreement on Code of Conduct.

The key findings indicate that the most common form of appearance of the enterprises' sustainability are: environmental certification of enterprise products; certification of the production process according to the international standards (quality management system implementation in accordance with ISO 9001, environmental management system in accordance with ISO 14001, etc.); providing decent pay and working conditions for the inhabitants in the region where the enterprise's facilities are present (see Table 6). 
Table 6. The most common forms of appearance for a socially responsible position in supply chain engineering in different firms

\begin{tabular}{|c|c|c|c|c|c|c|c|}
\hline $\begin{array}{l}\text { Forms of manifestation of a socially responsible position of } \\
\text { building a supply chain }\end{array}$ & Z & 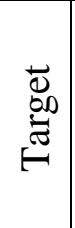 & $\underset{Z}{己}$ & 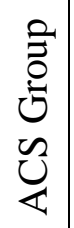 & 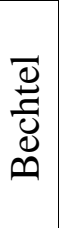 & 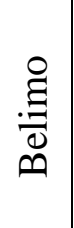 & 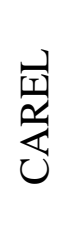 \\
\hline Company Code of Conduct and Social Responsibility & + & + & + & + & + & + & + \\
\hline Environmental certification of finished products & + & + & + & + & + & + & + \\
\hline Production of eco-products & - & - & - & - & + & - & - \\
\hline $\begin{array}{l}\text { Ensuring a sufficient level of remuneration and its conditions } \\
\text { for both the company and suppliers }\end{array}$ & + & + & + & + & + & + & + \\
\hline $\begin{array}{l}\text { Compliance and compliance with international human rights } \\
\text { standards and labor market rules }\end{array}$ & + & - & + & + & + & + & + \\
\hline Supplier compliance with environmental standards & $+/-$ & + & + & + & + & + & + \\
\hline Environmental certification (ISO14001, EMAS or equivalent) & + & + & + & + & + & + & + \\
\hline $\begin{array}{l}\text { Adjusting the quality of the materials supplied and their } \\
\text { compliance with RoHS and REACH (or equivalent) }\end{array}$ & + & + & + & + & + & $+/-$ & $+/-$ \\
\hline $\begin{array}{l}\text { Analysis of labor standards and practices of suppliers or } \\
\text { subcontractors }\end{array}$ & $+/-$ & $+/-$ & + & + & + & $+/-$ & $+/-$ \\
\hline Disposal adjustment of products RESY (or equivalent) & $+/-$ & $+1-$ & $+/-$ & $+/-$ & + & $+/-$ & $+1-$ \\
\hline
\end{tabular}

A well-developed database of mechanisms and tools, indicators used to evaluate chains, requires refinement and implementation in the activity of enterprises in the context of global requirements for supply chain construction. Each country must implement them, taking into account global requirements for the standardization and certification of goods, as well as adhering to the basic principles of socially oriented society.

\section{Conclusions}

Summing up, it is worth noting that the increasing importance of the environmental values in the contemporary world practice inevitably increases the role of various managerial approaches to their implementation in the business practice. On the other hand, there are forms of external control and environmental assessment for the companies' activity: such as various ratings, reports, indices. This inevitably pushes modern business to implement the "sustainability" principles in all aspects of its activities.

Implementation of the environmental aspects of social responsibility is not only an integral part of the modern companies' activity, but it rather permeates through all lines of the business chain through a continuous line. Global ratings of modern companies take into account not only their commitment to the social responsibility principle, but also the degree of implementation in the supply chains. The forms of appearance for the environmental responsibility are expanding, while the requirements for all suppliers, contractors, and stakeholders are increasing. 


\section{References}

100 Best Corporate Citizens. available at: https://www.3blassociation.com/files/yMblCg/100BestCorporateCitizens_2019.pdf

2018 Corporate Responsibility Report. The value of performance. Northrop Grumman. available at: https://www.northropgrumman.com/CorporateResponsibility/Documents/pdfs/2018noc-cr-report.pdf

Bechtel's Expectations for Suppliers' and Subcontractors' Conduct. available at: https://www.bechtel.com/getattachment/about-us/ethics-compliance/shared-values/suppliersubcontractor-expectations/Supplier-and-Subcontractor-Expectations-2017.pdf

Belimo Annual Report 2018. available at: https://www.belimo.com/mam/corporatecommunications/investor-relations/financial-reports/2018/Sustainability_Report_2018.pdf

CAREL and Sustainability. available at: https://www.carel.com/carel-and-sustainability

CAREL in the world. available at: https://www.carel.com/carel-in-the-world

David L. Anderson, Frank F. Britt, and Donavon J. Favre. The 7 Principles of Supply Chain Management. 2016.

available

at:

https://www.supplychain247.com/paper/the_7_principles_of_supply_chain_management

Environmental Protection. available at: https://www.carel.com/environmental-protection

Future at heart. 2018 Target Corporate Responsibility Report. available at: https://corporate.target.com/_media/TargetCorp/csr/pdf/2018_corporate_responsibility_report.pdf

Gartner Announces Rankings of the 2019 Supply Chain Top 25. available at: https://www.gartner.com/en/newsroom/press-releases/2019-05-16-gartner-announces-rankings-ofthe-2019-supply-chain-t

George Kokoris. Going Green can put your Business in the Black. - 2017. available at: http://www.supplychain247.com/paper/going_green_can_put_your_business_in_the_black

Supplier \& Subcontractor Expectations available at: https://www.bechtel.com/about-us/ethicscompliance/shared-values/supplier-subcontractor-expectations/

Lora Cecere. Building the Green Supply Chain. available at: http://www.supplychain247.com/paper/building_the_green_supply_chain

Management of the relationship with stakeholders. available at: https://www.grupoacs.com/ficheros_editor/File/05_responsabilidad_corporativa/00\%20PDFS/6.5. \%20Gesti\%C3\%B3n\%20de\%20la\%20Relaci\%C3\%B3n\%20con\%20los\%20Grupos\%20de\%20Inte r\%C3\%A9s_en.pdf

Managing Green Supply Chains: Best Practices and Long-term Solutions. available at: https://knowledge.wharton.upenn.edu/article/managing-green-supply-chains-best-practices-andlong-term-solutions/

Prashant Kumar \& Subhash Wagle. Greening the Supply Chain. - 2014. available at: http://www.supplychain247.com/paper/greening_the_supply_chain\#register

Suppliers and contractors. available at: https://www.grupoacs.com/corporateresponsibility/the-csr-policy-of-the-acs-group/suppliers-and-contractors/

Suppliers and contractors. available at: https://www.grupoacs.com/ficheros_editor/file/05_responsabilidad_corporativa/00\%20pdfs/6.7.\%2 Oproveedores\%20y\%20contratistas_en.pdf

Suppliers. available at: https://www.belimo.com/en_US/about/belimo/supplier-relationshipmanagement.html

Supply Chain Management. available at: https://www.carel.com/supply-chain-management

Supply chain. available at: https://www.vincifacilities.com/opportunities/supply-chain/

Sustainability Report. available at: https://www.belimo.com/mam/corporatecommunications/investor-relations/financial-reports/2018/Sustainability_Report_2018.pdf 